\title{
Entidheidungen des
}

(Dber $=$ Seeamts und der Seeämter des Deutithen Reidhs.

\author{
Gerausgegeben
}

iII

Reichsamt des Inmern.

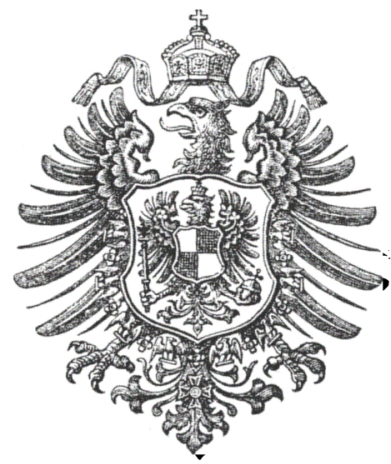

Siebenter $\mathfrak{B}$ and. Gejt $x$.

Gamburg.

Druat und Derlag vont E. friederidifen \& $\mathbb{C}_{0}$. 1887. 